\title{
UPAYA MENINGKATKAN PRESTASI BELAJAR MATEMATIKA \\ DENGAN METODE MENTOR BERBASIS TEAM-ASSISTED INDIVIDUALIZATION \\ KELAS VI SD NEGERI DEMAKIJO 1 TAHUN PELAJARAN 2017/2018
}

\author{
Tangsi Sasmito ${ }^{1}$
}

\begin{abstract}
Abstrak
Penelitian ini bertujuan mengetahui efektivitas penggunaan metode mentor berbasis TeamAssisted Individualization dalam pembelajaran Matematika dan peningkatan prestasi belajar siswa kelas VI dalam menyiapkan Ujian Sekolah Berstandar Nasional (USBN). Metode pembelajaran mentor berbasis Team-Assisted Individualization merupakan pengembangan metode pembelajaran tutor sebaya sebagai alternatif mengatasi permasalahan dalam pembelajaran kelas besar yang heterogen. Metode pembelajaran mentor berbasis TeamAssisted Individualization mengadaptasi perbedaan individu siswa secara akademik, pengelompokan siswa, pengelompokan kemampuan di dalam kelas, dan pengajaran terprogram. Pembentukan kelompok belajar berdasarkan analisis hasil tes menggunakan Student Proplem Analysis (S-P Analysis). Responden penelitian adalah 32 siswa kelas VI SD Negeri Demakijo 1. Analisis data menggunakan teknik statistik deskriptif. Hasil penelitian terhadap implementasi metode mentor berbasis Team-Assisted Individualization dalam pembelajaran Matematika menunjukkan aktivitas dan dinamika belajar siswa meningkat serta perubahan prestasi yang positif ditunjukkan dengan meningkatnya nilai rata-rata dari tes awal sampai dengan tes siklus III. Dengan Kriteria Ketuntasan Minimal (KKM) sebesar 7,50 diperoleh data 81,25\% (26 siswa) mencapai KKM. Efektivitas implementasi metode mentor berbasis Team-Assisted Individualization dalam pembelajaran mulai siklus I sampai dengan siklus III mampu menaikkan prestasi/nilai latihan USBN mata pelajaran Matematika sebesar 1,42 atau $21,65 \%$.
\end{abstract}

kata kunci: mentor, Team-Assisted Individualization , SP-Analysis

1 Guru di SD Negeri Demakijo 1, Dinas Pendidikan Kabupaten, Sleman, DIY (tangsi.sas@gmail.com) 
PENDAHULUAN

Dalam konteks sekolah, istilah belajar selalu dikaitkan dengan istilah mengajar, dimana belajar merupakan kegiatan yang diidentikkan kepada siswa yang menempati posisi sebagai subjek yang mencari ilmu, sedangkan istilah mengajar melekat pada guru sebagai pihak yang diidentikkan sebagai pemberi ilmu atau sumber ilmu. Interaksi antara guru dengan siswa yang demikian itu, sering dipahami sebagai proses Kegiatan Belajar Mengajar (KBM) atau istilah saat ini disebut proses pembelajaran. Seiring perkembangan waktu pengertian dan pemahaman terhadap konsep pembelajaran tersebut mengalami pergeseran. Paradigma pembelajaran bukan hanya sebagai transfer pengetahuan dari guru ke siswa tetapi merupakan suatu proses untuk mengubah tingkah laku dalam membentuk pengalaman yang bermakna bagi siswa. Belajar mengajar merupakan kegiatan dimana terjadi interaksi antara guru dengan siswa, serta siswa dengan siswa (Ahmad Susanto, 2013). Belajar merupakan proses perubahan yang dialami siswa dalam kemampuannya untuk bertingkah laku dengan cara yang baru sebagai hasil interaksi antara stimulus dan respon. Seseorang dianggap belajar jika ia mampu menunjukkan adanya perubahan tingkah laku (Asri Budiningsih, 2003).
Indikator keberhasilan proses pembelajaran jenjang Sekolah Dasar (SD) yang sekaligus merupakan salah satu indikator mutu pendidikan di satuan pendidikan adalah perolehan nilai Ujian Nasional (UN) atau Ujian Sekolah Bertaraf Nasional (USBN) Kelas VI yang meliputi mata pelajaran Ilmu Pengetahuan Alam, Matematika dan Bahasa Indonesia. Pandangan masyarakat tentang kualitas sekolah yang dilihat dari nilai hasil USBN tersebut memotivasi guru kelas VI khususnya dan sekolah pada umumnya untuk memberikan perhatian khusus pada proses pembelajaran siswa agar lulus dengan nilai USBN maksimal. Kajian teori menyatakan bahwa banyak bentuk, teknik, metode dan pendekatan pembelajaran yang bisa digunakan guru untuk meningkatkan prestasi belajar siswa, tetapi perlu dipahami bahwa tidak ada satupun metode atau teknik pembelajaran yang paling sempurna atau terbaik sehingga mampu membuat siswa berprestasi.

Selama tiga tahun terakhir pencapaian hasil Ujian Nasional (UN) siswa Kelas VI SD Negeri Demakijo 1, khususnya mata pelajaran Matematika belum sesuai target yang diinginkan, meskipun langkah strategis sudah dilakukan diantaranya pemberian pelajaran tambahan, mengintensifkan komunikasi sekolah dengan orang tua siswa, memperbanyak soal latihan atau simulasi, 
dan menyusun best practice sukses UN di awal tahun pelajaran. Rombongan belajar Kelas VI SD Negeri Demakijo 1 tahun pelajaran 2017/2018 terdiri dua kelas paralel masing-masing berjumlah 32 siswa. Secara normatif dengan jumlah siswa 32 anak, sama-sama mengikuti pembelajaran maka tidak ada jaminan bahwa semua siswa bisa mengikuti dan menguasai pelajaran dengan baik. Permasalahan klasik yang muncul saat pembelajaran guru dengan kelas besar yaitu terkadang siswa yang pandai akan merasa bosan dan jenuh ketika guru banyak memberikan perhatian dan bimbingan pada temannya yang lambat, sebaliknya siswa yang lambat semakin terpuruk dan berkesulitan belajar seandainya guru memberikan perhatian kepada siswa yang cepat/pandai. Fenomena tersebut menumbuhkan tekad dan motivasi untuk menyusun langkah strategis yang lebih spesifik dengan meningkatkan potensi yang dimiliki terkait keterampilan guru dalam mengelola pembelajaran dan memberdayakan siswa yang memiliki kompetensi atau mempunyai daya serap tinggi.

Tulisan ini merupakan bagian dari hasil penelitian dan usaha mengatasi permasalahan dalam meningkatkan prestasi belajar siswa kelas VI SD Negeri Demakijo 1 khususnya mata pelajaran
Matematika. Salah satu alternatif tindakan yang dilakukan adalah melaksanakan pembelajaran dengan menggunakan model pembelajaran mentor teman sebaya dan belajar kelompok untuk meminimalisir pengajaran individu dengan pendekatan kolaboratif Team-Assisted Individualization. Kelebihan pembelajaran dengan model mentor sebaya adalah memotivasi siswa yang pandai untuk lebih giat belajar dan siswa yang lemah terbimbing lebih optimal tanpa rasa takut, tertekan dan canggung untuk bertanya. Tekad dan motivasi menyelenggarakan pembelajaran dengan implementasi mentor ini dilandasi oleh kesadaran bahwa belajar itu seharusnya tidak hanya bergantung pada guru satu-satunya sumber ilmu tetapi suatu kesadaran untuk memberdayakan potensi dan keakraban siswa sebagai upaya atas dasar keinginan untuk menumbuhkan suasana belajar antara siswa.

$$
\text { Pendekatan }
$$

Team-Assisted Individualization merupakan sebuah program pedagogik yang berusaha mengadaptasi pembelajaran dengan perbedaan individual siswa secara akademik (Miftahul Huda, 2010). Pengembangan

Team-Assisted Individualization dapat mendukung praktik-praktik ruang kelas seperti pengelompokan siswa, pengelompokan kemampuan di dalam kelas, pengajaran 
terprogram dan pengajaran berbasis komputer. Tujuan Team-Assisted Individualization adalah untuk meminimalisir pengajaran individual yang kurang efektif dan ditujukan untuk meningkatkan pengetahuan, kemampuan serta motivasi siswa dengan belajar kelompok.

Menurut Slavin dalam Miftahul Huda (2010) beberapa kelebihan manfaat Team-Assisted Individualization dalam memenuhi kriteria pembelajaran efektif, yaitu (1) meminimalisir keterlibatan guru dalam pemeriksaan dan pengelolaan rutin; (2) melibatkan guru mengajar pada kelompok-kelompok kecil yang heterogen; (3) mudah dilaksanakan oleh siswa karena teknik operasionalnya sederhana, (4) memotivasi siswa untuk mempelajari materi yang diberikan dengan cepat dan akurat; (5) memungkinkan siswa bekerjasama dengan siswa lain yang berbeda-beda sehingga tercipta sikap positif diantara mereka. Tahapan pembelajaran yang mengadaptasi pendekatan Team-Assisted

Individualization adalah (1) tim, yaitu siswa dibagi dalam kelompok-kelompok kecil beranggotakan 4-5 siswa; (2) tes penempatan, yaitu siswa melaksanakan pretest kemudian ditempatkan pada tingkatan yang sesuai; (3) materi, yaitu siswa mempelajari materi pelajaran yang akan didiskusikan dan dibahas; (4) belajar kelompok, yaitu melakukan belajar secara berkelompok dalam satu tim; (5) skor dan rekognisi, yaitu hasil kerja siswa diberi skor dan tim yang bagus mendapatkan penghargaan guru; (6) kelompok pengajaran, yaitu guru memberikan pengajaran pada setiap kelompok tentang materi yang didiskusikan, dan (7) tes fakta yaitu siswa mengerjakan tes-tes untuk membuktikan kemampuannya.

Berdasarkan penelitian dan kajian yang relevan tentang metode mentor atau tutor sebaya dalam pembelajaran merupakan salah satu alternatif untuk meningkatkan motivasi dan prestasi belajar berbasis pemberdayaan potensi siswa. Kelebihan metode mentor/tutor sebaya antara lain: (1) menyampaikan informasi lebih mudah sebab bahasanya sama, (2) kesulitan lebih terbuka, (3) suasana yang rileks menghilangkan rasa takut, (4) mempererat persahabatan, (5) ada perhatian terhadap perbedaan karaktersitik, (6) konsep mudah dipahami, dan (7) siswa tertarik untuk bertanggung jawab dan mengembangkan kreativitas. Sedangkan kelemahan metode mentor adalah: (1) kurang serius dalam belajar, (2) jika siswa punya masalah dengan mentor ia akan malu bertanya, (3) sulit menentukan mentor yang tepat, (4) tidak semua siswa pandai dapat menjadi mentor.

Dengan metode pembelajaran mentor berbasis Team-Assisted 
Individualization diharapkan dinamika kelompok semakin aktif, meningkatkan motivasi belajar dan meningkatkan penguasaan materi sehingga kompetensi siswa terpantau dan terukur yang pada akhirnya mampu meraih prestasi belajar optimal. Metode pembelajaran mentor dengan berbasis kelompok belajar dipilih untuk memecahkan permasalahan terkait prestasi belajar Matematika Kelas VI di SD Negeri Demakijo 1 dalam usaha meningkatkan nilai USBN tahun pelajaran 2017/2018.

Langkah-langkah pembelajaran yang dilakukan adalah siswa diberikan tes awal (pre-test) sebagai tes penempatan pada tingkatan yang sesuai kemudian dibuatkan kelompok belajar dengan mempertimbangkan analisis hasil tes. Dari sejumlah 32 siswa dibentuk dalam kelompok atau tim masing-masing beranggotakan 8 anak dengan kemampuan yang berbeda-beda selanjutnya memilih mentor dari masing-masing kelompok tersebut dengan ketentuan dipilih siswa yang memiliki prestasi dan daya serap tinggi. Siswa mempelajari materi pelajaran dalam kelompok dengan bimbingan mentor diakhiri pemberian latihan soal, diskusi kelompok dan unjuk kerja. Akhir pembelajaran siswa diberi penghargaan berupa skor melalui pembahasan dan diskusi, kelompok terbaik mendapatkan penghargaan dan membantu guru memberikan penguatan kepada kelompok yang lain. Akhir pembelajaran guru meminta siswa mengerjakan tes untuk membuktikan kemampuannya.

Penelitian dilakukan dengan tujuan: (1) mengetahui efektivitas penggunaan metode mentor dalam pembelajaran Matematika kelas VI, dan (2) mengetahui peningkatan prestasi belajar Matematika siswa kelas VI dalam mengikuti tes penyiapan USBN dengan pembelajaran mentor berbasis Team-Assisted Individualization .

\section{METODE PENELITIAN}

Penelitian dilaksanakan di SD Negeri Demakijo 1, sekolah berada di wilayah UPT Pelayanan Pendidikan Kecamatan Gamping Kabupaten Sleman. Sekolah ini terletak di Jalan Godean Km 5,5 Guyangan, Nogotirto, Gamping, Sleman, Yogyakarta.

Sumber data yang digunakan adalah data hasil tes latihan USBN dari kondisi awal penelitian sampai dengan pelaksanaan tindakan akhir. Data kemampuan awal menggunakan hasil tes latihan USBN tahap I dari Dinas Pendidikan Kabupaten Sleman yang diasumsikan sudah terstandar dan teruji karena dibuat oleh tim penyusun soal USBN tingkat kabupaten dan telah melalui uji coba butir soal. Sampel responden 
mengambil siswa salah satu kelas VI di SD

Negeri Demakijo 1 yaitu kelas VIA dengan pertimbangan kemampuan siswa, kemampuan guru, fasilitas dan jumlah siswa sama dengan kelas VIB.

Teknik pengumpulan data dalam penelitian menggunakan teknik observasi dan tes serta catatan hasil refleksi/diskusi dengan partner atau mitra peneliti. Teknik pengumpulan disesuaikan dengan ketersediaan sarana dan prasarana serta kemampuan peneliti dan kolaborator. Instrumen yang digunakan untuk mengumpulkan informasi dan data-data adalah instrumen tabulasi, grafik, instrumen analisis butir tes dan nilai hasil belajar, serta instrumen soal latihan USBN tahun pelajaran 2017/2018.

Tindakan yang dilakukan sebelum kegiatan penelitian adalah penyusunan best practice untuk meraih target nilai USBN tahun 2018 khususnya mata pelajaran Matematika kemudian mengimplementasikan ketentuan yang ditulis dalam kegiatan pembelajaran. Setelah selesai mengikuti proses pembelajaran yang dilakukan guru berdasarkan best practice tersebut, siswa diberi kesempatan mengerjakan tes awal kesiapan USBN (latihan tahap I). Hasil tes tahap I USBN selanjutnya dianalisis untuk mengetahui skor masing-masing item soal dan skor masing-masing siswa sehingga diketahui materi yang belum terkuasai, butir soal yang sulit dan peta kompetensi siswa meliputi kekuatan dan kelemahan serta kemampuan dalam penguasaan materi/item soal. Selain itu hasil analisis bisa memetakan siswa yang mampu mencapai kriteria ketuntasan minimal (KKM) maupun siswa yang perlu mendapatkan perhatian khusus untuk pendampingan dan pembimbingan karena masih dibawah KKM. Siswa dikelompokkan berdasar nilai capaian tes dengan sebaran yang merata, siswa yang memperoleh nilai tinggi ditunjuk sebagai mentor/pembimbing dalam kelompoknya. Setelah melakukan belajar dalam kelompok yang dibimbing mentor, selanjutnya siswa mengerjakan simulasi USBN tes tahap II. Hasil tes dianalisis dengan cara yang sama untuk membentuk kelompok seperti sebelumnya dengan formasi baru dan memilih mentor yang baru atau mentor pendamping dari kelompoknya berdasarkan prestasi dan daya serap, begitu seterusnya sampai target keberhasilan terpenuhi yaitu minimal $70 \%$ dari jumlah siswa di kelas VI mencapai $\operatorname{KKM} 7,50$.

Analisis hasil tes yang dipergunakan untuk memberikan gambaran atau kesimpulan objektif terhadap responden dilihat dari instrumen/item soal dan siswa yang mengerjakan adalah Student Proplem Analysis (S-P Analysis). Bentuk tes yang 
sesuai dengan S-P Analysis adalah bentuk tes objektif atau soal dengan jawaban pasti, jika siswa menjawab benar maka diberikan nilai 1 (satu) dan jawaban salah nilainya 0 (nol). Pengembangan S-P Analysis bisa digunakan pada soal essay atau jawaban nilai bervariasi (berkisar 0-5) dengan nilai 0 (nol) untuk skor jawaban antara 0-2 dan nilai 1 (satu) untuk skor jawaban antara 3-5.

Rekomendasi dari analisis tes yang menggunakan S-P Analysis adalah skor tinggi pada jumlah item soal menunjukkan bahwa item soal mudah dan mampu dijawab benar oleh siswa artinya kompetensi untuk indikator item tersebut dikuasai siswa, sebaliknya semakin rendah skor item soal berarti soal tersebut sulit atau kompetensi indikator item soal tersebut tidak dikuasai siswa. Sedangkan skor tinggi untuk item siswa menunjukkan nilai yang dicapai, kemampuan siswa mengerjakan soal dengan benar atau berapa banyak siswa yang perlu mendapatkan perhatian khusus.

Indikator keberhasilan dari tindakan yang ingin dicapai dalam penelitian ini adalah prestasi belajar Matematika yang meningkat dari sebelumnya dengan target keberhasilan tercapainya KKM kelas VI 7,50 oleh minimal 70\% siswa dari jumlah 32 anak. Penelitian yang dilaksanakan menggunakan sistem spiral refleksi diri mulai dari rencana, tindakan, pengamatan, refleksi, dan perencanaan kembali yang merupakan dasar untuk suatu rencana pemecahan masalah tahapan berikutnya.

\section{HASIL DAN PEMBAHASAN}

\section{Deskripsi Kondisi Awal}

Awal tahun pelajaran 2017/2018 sekolah menyusun best practice sukses Ujian Nasional (UN) sebagai pedoman perbaikan, referensi dan refleksi terhadap pembelajaran agar pelaksanaan UN/USBN berhasil meraih nilai pretasi yang optimal. Guru melaksanakan pembelajaran dan telaah materi mengacu pada best practice sekolah, selanjutnya siswa diberi kesempatan melakukan ujicoba atau simulasi USBN. Analisis data hasil tes Matematika latihan USBN kelas VI tahap I sebagai tes kemampuan awal, dengan jumlah siswa 32 anak dan menggunakan kriteria ketuntasan minimal (KKM) 7,50 diperoleh nilai rata-rata tes 6,56 dengan jumlah siswa mencapai KKM sebesar $37,50 \%$ (12 siswa) sehingga ada $62,50 \%$ siswa masih dibawah kriteria ketuntasan(KKM) yang diharapkan.

\section{Deskripsi Siklus I}

Setelah dilakukan analisis hasil tes kemampuan awal menggunakan S-P Analysis, tahapan selanjutnya adalah treatment siswa dalam pembelajaran siklus I yang meliputi: 
1. Perencanaan siklus I

Perencanaan adalah langkah awal yang dilakukan saat akan memulai tindakan. Kegiatan dalam membuat rencana tindakan adalah; (a) merumuskan tujuan penyelesaian masalah dengan tindakan inovasi dan tindakan menganalisis tes hasil belajar; (b) merumuskan indikator dan alternatif keberhasilan pembelajaran Matematika dengan KKM 7,50; (c) menyiapkan metode pembelajaran dengan mentoring untuk meningkatkan prestasi belajar siswa kelas VI pada mata pelajaran Matematika; (d) menyiapkan materi ajar dan bahan diskusi, dan (e) menyiapkan istrumen evaluasi dan analisis hasil belajar.

\section{Pelaksanaan tindakan siklus I}

Guru mengembangkan pembelajaran Matematika dengan tetap mengacu pada indikator kisi-kisi soal USBN sebagai pembelajaran umum. Pembelajaran mentor dalam kelompok belajar difokuskan pada nomor item/indikator soal yang termasuk sukar berdasakan analisis butir soal/hasil belajar. Pembelajaran siklus I memuat langkah-langkah berikut:

Pendahuluan, kegiatan ini meliputi: (1) apersepsi; (2) menyampaikan tujuan dan menetapkan target capaian KKM 7,50 ; (3) mengulas materi soal pretest (kemampuan awal).

Kegiatan Inti, meliputi : (1) membentuk kelompok belajar beranggotakan 8 orang, guru menunjuk 1 orang mentor tiap kelompok berdasarkan pemetaan kompetensi dan analisis tes kemampuan awal; (2) guru membagikan SKL dan indikator yang akan dipelajari, kemudian menjelaskan tugas mentor dalam kelompok dan fokus pada indikator yang harus dikuasai untuk mendampingi dan membimbing teman-temannya dalam kelompok; (3) guru dan mentor membimbing siswa dalam kelompok untuk belajar memecahkan masalah, diskusi dan memprediksi bentuk dan jenis soal sesuai kisi-kisi/SKL pada item soal berkategori sukar; (4) mentor melakukan pendampingan dan bimbingan dalam belajar kelompok, latihan menyelesaikan masalah dengan mengerjakan latihan soal sukar mengacu pada kisi-kisi, kesulitan yang tidak terselesaikan dalam kelompok dikonsultasikan kepada narasumber/guru; (5) membacakan hasil mentoring dalam tugas kelompok, meliputi; prosedur menyelesaikan masalah, mengulang penjelasan materi, mereview dan merevisi pekerjaan sendiri/kelompok kemudian bersama guru membuat kesimpulan, dan (6) kelompok yang terbaik dalam pekerjaan diberikan penghargaan dan skor, kemudian bersama guru memberikan penguatan pada kelompok yang lain.

Kegiatan Akhir, meliputi : (1) membuat kesimpulan bersama ketercapaian penguasaan materi dan 
indikator kompetensi dalam mentoring belajar ; (2) merefleksi kelemahan dan kekuatan dalam pembelajaran selama mentoring

Tindak Lanjut, meliputi : (1) memberi PR sesuai dengan indikator kisikisi item sukar dan (2) melaksanakan tes latihan USBN (simulasi soal).

\section{Deskripsi Siklus II}

Setelah dilaksanakan analisis butir soal tes akhir siklus I, tahapan selanjutnya adalah treatment pembelajaran dalam siklus II, meliputi:

\section{Perencanaan siklus II}

Langkah awal yang dilakukan adalah persiapan pelaksanaan tindakan dalam siklus II meliputi: (1) mengidentifikasi permasalahan dari siklus I yang akan dicari solusinya; (2) merumuskan tujuan penyelesaian masalah dengan melakukan inovasi pembelajaran dan menganalisis tes hasil belajar siklus I untuk mengetahui peta prestasi, penguasaan kompetensi dan kelemahan siswa kelas VI; (3) merumuskan langkah-langkah kegiatan pembelajaran mentor dalam kelompok belajar dengan melakukan sosialisasi kepada guru dan siswa kelas VI mengenai metode mentor yang menggunakan lebih dari 1 orang mento, yaitu mentor berjenjang atau multi level mentor agar siswa yang lambat bisa terbimbing dengan efektif; (4) menyiapkan instrumen evaluasi dan analisis hasil belajar.

2. Pelaksanaan tindakan siklus II

Metode mentor dalam pembelajaran difokuskan pada item/indikator soal yang termasuk sukar dan pengembangan pembelajaran pada item yang kategori sedang dan mudah berdasarkan analisis butir soal/hasil belajar. Proses pembelajaran yang didesain guru memuat langkah-langkah berikut:

Pendahuluan, meliputi: (1) apersepsi; (2) menyampaikan tujuan pembelajaran dan menetapkan target hasil pembelajaran yaitu mencapai KKM 7,50; menginformasikan hasil tes siklus I dan peta kelompok dalam siklus II sekaligus kriteria mentor kelompok

Kegiatan Inti, meliputi : (1) membentuk kelompok belajar beranggotakan 5 orang, guru menunjuk 1 orang mentor utama dan 2 mentor pendamping dalam kelompok berdasarkan kompetensi dan analisis tes siklus 1 (lihat gambar 1)

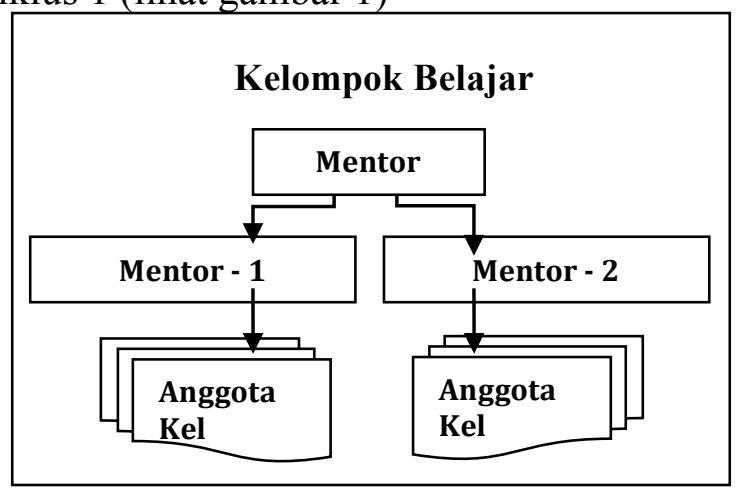

Gambar 1 Skema Mentor dalam Belajar Kelompok 
(2) guru menjelaskan tugas mentor dalam kelompok dan fokus pada indikator yang harus dikuasai untuk mendampingi dan membimbing teman-temannya yang berkesulitan belajar dalam kelompok; (3) guru dan mentor membimbing siswa dalam kelompok untuk belajar menyelesaikan masalah, diskusi, dan memprediksi bentuk dan jenis soal sesuai kisi-kisi/SKL pada item soal berkategori sukar; (4) mentor utama melakukan pendampingan dan bimbingan kepada anggota kelompok dibantu mentor pendamping untuk mengerjakan latihan soal sukar mengacu pada kisi-kisi, kesulitan dan permasalahan yang tidak terselesaikan dalam kelompok dikonsultasikan kepada narasumber guru.; (5) membacakan hasil mentoring belajar item sukar, meliputi: mengulang penjelasan materi, mereview dan merevisi pekerjaan sendiri/kelompok, dan bersama guru membuat kesimpulan.

Kegiatan Akhir, meliputi: (1) membahas soal evaluasi dalam pembelajaran dengan prioritas soal kategori sukar berdasar kisikisi SKL; (2) merefleksi kelemahan dan kekuatan dalam pembelajaran yang dilaksanakan dengan mentor.

Tindak Lanjut, meliputi: (1) memberi tugas sesuai dengan prioritas pembahasan yaitu indikator kisi-kisi kategori sukar; (2) melaksanakan tes latihan USBN (simulasi soal).

\section{Deskripsi Siklus III}

Setelah dilaksanakan analisis butir soal tes akhir siklus II, ternyata masih ada potensi yang bisa dikembangkan dalam tahapan selanjutnya dengan treatment pembelajaran dalam siklus III, meliputi:

\section{Perencanaan sikus III}

Langkah awal yang dilakukan saat memulai tindakan dalam siklus III, sebagai berikut: (1) mengidentifikasi permasalahan dari siklus II yang akan dicari solusinya; (2) merencanakan inovasi pembelajaran dan menganalisis tes hasil belajar siklus II untuk mengetahui peta prestasi, penguasaan kompetensi dan kelemahan siswa kelas VI; (3) merumuskan langkahlangkah kegiatan pembelajaran dan menyampaikan tujuan penerapan tindakan yang akan dilakukan; (4) menyiapkan instrumen evaluasi dan analisis hasil belajar.

2. Pelaksanaan tindakan siklus III

Pendahuluan, meliputi : (1) melakukan apersepsi untuk menghubungkan pengetahuan dan konsep Matematika yang telah dimiliki; (2) menginformasikan hasil tes siklus II dan peta kelompok sekaligus kriteria mentor dalam kelompoknya; (3) menyampaikan tujuan pembelajaran dan menetapkan target hasil pembelajaran yaitu mencapai KKM 7,50; menginformasikan hasil tes siklus II dan peta kelompok dalam siklus III sekaligus kriteria mentornya. 
Kegiatan Inti, meliputi : (1) membentuk kelompok belajar beranggotakan 5 orang, guru menunjuk 1 orang mentor utama dan 2 mentor pendamping dalam kelompok berdasarkan pemetaan kompetensi dan analisis daya serap pada tes siklus II; (2) guru memberikan telaah materi yang akan dipelajari selanjutnya, menjelaskan tugas mentor dalam kelompok untuk fokus pada indikator yang harus dikuasai dalam mendampingi dan membimbing temantemannya dalam kelompok; (3) guru dan siswa membahas dan menelaah indikator kategori sukar, menyampaikan ide gagasan, langkah praktis dalam strategi simulasi penyelesaian soal yang sukar; (4) guru meminta kepada mentor utama mengkoordinasikan dengan mentor pendamping agar melaksanakan bimbingan dalam kelompoknya dengan mengkaji indikator, konsep sukar dan belum dikuasai kemudian simulasi mengerjakan soal dalam kelompok; (5) mentor utama dan mentor pendamping melakukan pendampingan dan bimbingan kepada anggota kelompok untuk mengerjakan latihan soal sukar mengacu pada kisi-kisi. Kesulitan dan hambatan yang ditemui dalam kelompok/kelas yang tidak terselesaikan dikonsultasikan kepada mentor utama selanjutnya kepada narasumber yaitu guru; (6) setelah menyelesaikan kerja dalam kelompok, siswa diminta mengkomunikasikan hasil kerja dan mempresentasikan di depan kelas, siswa yang lain menanggapi; (7) membacakan hasil mentoring belajar item sukar, meliputi: prosedur menyelesaikan soal, rumus praktis, penjelasan materi, mereview dan merevisi pekerjaan sendiri/kelompok kemudian bersama guru membuat kesimpulan.

Kegiatan Akhir, meliputi: (1) membahas soal evaluasi dalam pertemuan pembelajaran; (2) membuat kesimpulan bersama ketercapaian penguasaan materi dan indikator kompetensi dalam mentoring belajar

Tindak Lanjut,meliputi : (1) memberi tugas sesuai dengan indikator kisi-kisi USBN kategori sukar; (2) melaksanakan tes latihan USBN.

\section{Pembahasan Tiap Siklus:}

\section{Pembahasan Siklus I}

Dalam pelaksanaan tindakan siklus I, pembelajaran berjalan kondusif, siswa semangat dalam mengikuti pembelajaran. Hal ini tampak saat dibentuk dalam kelompok kemudian menunjuk mentor dari kelompok tersebut.

Catatan yang diperoleh dari pengamatan selama kegiatan siklus I, sebagai berikut: (1) siswa lebih aktif dan bersemangat dengan nuansa pembelajaran yang berbeda; (2) semua anggota kelompok dan mentor kelompok tampak 
aktif belajar; (3) siswa tidak canggung untuk diskusi dan melakukan tanya jawab dengan mentornya; (4) terjalin interaksi sosial antar siswa yang dinamis dan saling menghargai dalam diskusi kelompok.

Dari hasil analisis data selama proses pembelajaran siklus I, diperoleh data sebagai berikut: (1) analisis data hasil belajar Matematika pada Siklus I kelas VI mencapai rata-rata prestasi belajar 7,19 dari 6,56 meningkat 0,63 atau $9,60 \%$ dari tes awal; (2) analisis data pada tes siklus I disimpulkan bahwa kelas VI ada 25,00\% siswa sudah mencapai ketuntasan minimal (KKM) 7,50. Implementasi metode mentor berbasis kelompok belajar (Team-Assisted Individualization ) mampu meningkatkan prestasi $\quad 0,63$ atau $9,60 \%$ dengan ketercapaian KKM baru 25\% sehingga masih perlu ditindaklanjuti dalam siklus berikutnya.

\section{Pembahasan Siklus II}

Dalam pelaksanaan tindakan siklus II, pembelajaran menjadi berjalan lebih kondusif, siswa lebih antusias dan semangat dalam mengikuti pembelajaran. Hal ini tampak saat dibentuk kelompok belajar kemudian memilih 3 mentor dari kelompok tersebut yaitu 1 mentor utama dan 2 mentor pendamping. Mentor dipilih berdasarkan angka perolehan nilai prestasi belajar pada tes siklus sebelumnya.

Catatan yang diperoleh dari pengamatan selama kegiatan siklus II, sebagai berikut: (1) siswa lebih aktif bersemangat dengan nuansa pembelajaran yang lebih intens; (2) semua anggota kelompok dan mentor kelompok tampak aktif belajar; (3) siswa yang lambat belajar lebih termotivasi untuk belajar dalam bimbingan mentor, 1 mentor membimbing 2 siswa dalam kelompoknya; (4) siswa tidak canggung untuk diskusi dan melakukan tanya jawab dengan mentornya; (5) terjalin interaksi sosial antar siswa yang dinamis dan saling menghargai dalam diskusi kelompok.

Dari hasil analisis data selama proses pembelajaran siklus II, diperoleh data sebagai berikut: (1) analisis data hasil belajar Matematika pada siklus II kelas VI mencapai rata-rata prestasi belajar 7,67 dari 7,19 meningkat 0,48 atau $6,68 \%$ dari sebelumnya; (2) analisis data pada tes siklus II disimpulkan bahwa kelas VI ada 59,38\% (19 siswa) sudah mencapai Kriteria Ketuntasan Minimal (KKM) 7,50. Jumlah siswa yang mencapai KKM meningkat $34,38 \%$ dari pembelajaran siklus sebelumnya, sehingga masih berpotensi untuk ditingkatkan dalam pembelajaran siklus berikutnya.

\section{Pembahasan Siklus III}

Dalam pelaksanaan tindakan siklus III, pembelajaran menjadi berjalan lebih komunikatif dan dinamis sehingga siswa antusias dan semangat dalam mengikuti pembelajaran. Hal ini tampak saat mentor 
lebih siap dan paham terhadap tugasnya, 1 mentor membimbing 2 siswa, mentor dipilih berdasarkan angka perolehan nilai prestasi belajar pada tes siklus sebelumnya.

Catatan yang diperoleh dari pengamatan selama kegiatan siklus III, sebagai berikut: (1) siswa belajar dalam kelompok yang lebih kecil; (2) siswa bersemangat dengan nuansa pembelajaran yang lebih intensif; (3) semua anggota kelompok dan mentor kelompok tampak aktif belajar; (4) siswa yang lambat belajar lebih termotivasi untuk belajar dengan bimbingan mentor semi privat karena 1 mentor hanya membimbing 2 siswa dalam kelompoknya; (4) siswa tidak canggung untuk diskusi dan melakukan tanya jawab dengan mentornya; (5) terjalin interaksi sosial antar siswa yang dinamis dan saling menghargai dalam diskusi kelompok.

Dari hasil analisis data selama proses pembelajaran siklus III, diperoleh data sebagai berikut: (1) analisis data hasil belajar Matematika pada Siklus III kelas VI mencapai rata-rata prestasi belajar 7,98 dari 7,67 meningkat 0,31 atau 4,04\% dari sebelumnya; (2) analisis data pada tes siklus III disimpulkan bahwa siswa kelas VI yang mencapai KKM 7,50 ada 81,25\% (26 siswa), terjadi peningkatan positif
$21,87 \%$ dari pembelajaran siklus sebelumnya. Dengan demikian pembelajaran siklus III dianggap berhasil karena target siswa mencapai KKM melebihi target awal siklus yaitu 70\%.

\section{Pembahasan Antar Siklus}

Penguasaan materi dan kompetensi siswa kelas VI mata pelajaran Matematika terhadap indikator kisi-kisi USBN mengalami perubahan positif dan peningkatan prestasi yang signifikan. Beberapa catatan diperoleh selam pengamatan antar siklus, adalah: (1) pembelajaran mentor berbasis TeamAssisted Individualization merupakan inovasi pembelajaran yang memberikan nuansa baru sehingga memotivasi siswa untuk aktif; (2) pendekatan Team-Assisted Individualization mampu menstimulus siswa menjadi lebih aktif dan dinamis dalam belajar kelompok; (3) peran guru dapat diminimalisir terkait pembelajaran individu; (4) guru lebih berperan sebagai narasumber dan fasilitator; (5) terjalin interaksi sosial antar siswa yang dinamis dan saling menghargai dalam diskusi kelompok. Perubahan data antar siklus berdasarkan analisis hasil tes, ditampilkan dalam rekapitulasi analisis tes akhir antar siklus (Tabel 1). 
Tabel 1

Rekapitulasi Analisis Tes Akhir Antar Siklus

\begin{tabular}{|ccc|c|c|c|c|}
\hline \multicolumn{2}{|c|}{ Nilai } & Tes awal & Siklus I & Siklus II & Siklus III \\
\hline 0,00 & - & 2,00 & 0 & 0 & 0 & 0 \\
\hline 2,10 & - & 4,00 & 1 & 0 & 0 & 0 \\
\hline $4,10-$ & 6,00 & 17 & 3 & 0 & 2 \\
\hline $6,10-$ & 8,00 & 6 & 29 & 23 & 14 \\
\hline $8,10-$ & $-10,00$ & 8 & 0 & 9 & 16 \\
\hline
\end{tabular}

*pembulatan

Hasil pengamatan pembelajaran antar siklus adalah aktivitas dan dinamika belajar siswa menjadi meningkat dan mengalami perubahan positif, rata-rata nilai hasil tes siklus I adalah 7,19 meningkat 0,63 dari tes awal; rata-rata nilai siklus II hasil 7,67 dari 7,19 meningkat 0,48 ; dan rata-rata nilai siklus III hasilnya 7,98 dari 7,67 meningkat 0,31 . Peningkatan prestasi belajar antar siklus terkait rekapitulasi rata-rata hasil tes akhir antar siklus digambarkan dalam grafik peningkatan rata-rata prestasi antar siklus (gambar 2).

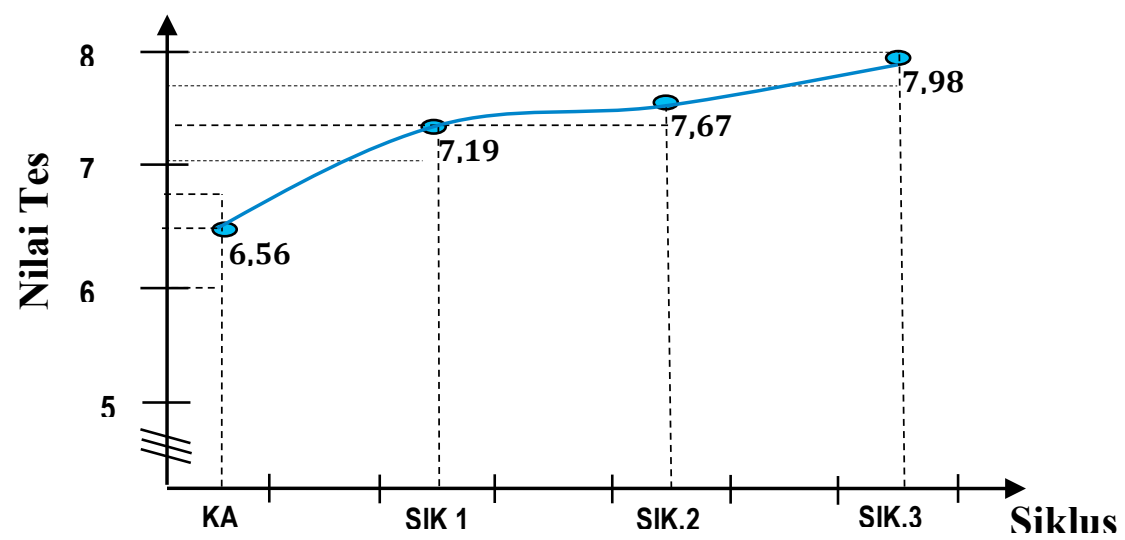

Gambar 2 Grafik Peningkatan Rata-Rata Prestasi Antar Siklus

Hasil analisis tes latihan USBN setelah siswa mengikuti pembelajaran Matematika dengan mengimplementasi metode mentor berbasis Team-Assisted Individualization yang dilaksanakan antar siklus, yaitu: (1) pembelajaran dengan metode mentor berbasis Team-Assisted Individualization dari siklus I sampai dengan siklus III dapat meningkatkan prestasi belajar, dibuktikan kenaikan ratarata nilai siswa dan prosentase siswa mencapai KKM 7,50 yang positif antar siklus sebanyak $81,25 \%$; (2) akhir siklus III grafik penguasaan materi mendekati normal dan prestasi belajar siswa kelas VI menunjukkan pencapaian nilai paling 
tinggi dibandingkan dengan siklus sebelumnya dengan rata-rata nilai 7,98 di atas KKM yang ditargetkan yaitu 7,50; dan (3) setelah pembelajaran dan simulasi USBN dilaksanakan dalam siklus III, diperoleh hasil prestasi rata-rata siswa kelas VI adalah 7,98 dengan grafik prestasi sudah mendekati normal dan kecenderungan konsisten maka direkomendasikan bahwa siswa kelas VI SD Negeri Demakijo 1 sudah siap menempuh USBN 2017 yang sesungguhnya dan pembelajaran siklus III dianggap berhasil atau selesai.

\section{KESIMPULAN}

\section{Berdasarkan uraian dan pembahasan disimpulkan bahwa upaya meningkatkan prestasi belajar Matematika siswa kelas VI SD Negeri Demakijo 1 tahun pelajaran 2017/2018 dengan pembelajaran mentoring berbasis Team- Assisted Individualization diperoleh hasil sebagai berikut:}

Pertama, Akhir siklus III menunjukkan kemampuan rata-rata prestasi belajar kelas VI adalah 7,98 dari kemampuan awal 6,56 dan mampu menaikkan prestasi/nilai latihan USBN mata pelajaran Matematika sebesar 1,42 atau $21,65 \%$ sehingga pembelajaran mentor berbasis Team-Assisted Individualization dinyatakan efektif diimplementasikan dalam pembelajaran untuk meningkatkan prestasi belajar Matematika di SD Negeri Demakijo 1.

Kedua, Sesudah guru menerapkan metode mentor berbasis Team-Assisted Individualization dalam pembelajaran maka aktivitas dan dinamika belajar siswa menjadi meningkat dan mengalami perubahan positif sebagai berikut: ratarata nilai hasil tes siklus I adalah 7,19 meningkat 0,63 atau $9,60 \%$ dari tes awal; rata-rata nilai siklus II hasil 7,67 dari 7,19 meningkat 0,48 atau $6,68 \%$; dan rata-rata nilai siklus III hasilnya 7,98 dari 7,67 meningkat $\quad 0,31$ atau $4,04 \%$. Ketercapaian prestasi belajar Matematika kelas VI dengan nilai kriteria ketuntasan minimal (KKM) sebesar 7,50 diperoleh data $81,25 \%$ (26 siswa) siswa mencapai KKM.

\section{DAFTAR PUSTAKA}

Ahmad Susanto (2013). Teori Belajar Pembelajaran. Jakarta : Kencana

Agus Suprijono (2010). Cooperative Learning Teori dan Aplikasi PAIKEM. Yogyakarta: Pustaka Pelajar

Budiningsih, Asri. (2005). Belajar dan Pembelajaran. Yogyakarta: FIP UNY

Depdiknas (2008). Pedoman Peningkatan Kinerja Kepala Sekolah. Jakarta: dirjendikdasmen 
Miftahul Huda (2018). Model-Model Pengajaran dan Pembelajaran. Malang: Pustaka Pelajar

Mukminan. (1998). Belajar dan Pembelajaran. Yogyakarta: IKIP Yogyakarta

Mushlihin Al-Hafizh (2013). Memahami Hal Penting dan Manfaat MLM Belajar. www.mushlihin.com tgl 29 nov 2013 diambil 10-12-2016

Ngadirin (2003). Analisis Hasil Tes (Student-Problem Analysis). Jakarta: Dirjendikdasmen

Poerwadarminta (2002). Kamus Umum Bahasa Indonesia. Jakarta: Rineka Cipta

Safitri, Heni. (2006). Pengantar Pendidikan Jarak Jauh (PJJ). Jakarta: Depdiknas

Suhardjono (2010). Penelitian Tindakan Kelas dan Penelitian Tindakan Sekolah. Malang: Cakrawala Indonesia

Sri Rumini.(1995). Psikologi Perkembangan.Yogyakarta: IKIP Yogyakarta

Susilowati, dkk (2009). Pembelajaran Kelas Rangkap. Direktorat Jenderal Pendidikan Tinggi Departemen Pendidikan Nasional.

Undang-Undang nomor 14 tahun 2005 tentang Guru dan Dosen

Zubaidah Amir (2016). Psikologi Pembelajaran Matematika. Yogyakarta: Aswaja Pressindo 